\title{
The Stromal Activity of Mesenchymal Stromal Cells
}

\author{
Wolfgang Wagner ${ }^{a}$ b Rainer Saffrich ${ }^{a}$ Anthony D. Ho \\ a Department of Medicine V, \\ ${ }^{b}$ Department of Physiology and Pathophysiology, University of Heidelberg, Germany
}

\section{Key Words}

Mesenchymal stem cell · Culture conditions ·

Microenvironment - Differentiation .

Hematopoietic stem cells · Cell-cell interaction

\section{Summary}

The mechanism that regulates self-renewal and differentiation of hematopoietic stem cells (HSC) is a central question in stem cell biology that might ultimately lead to reliable protocols for in vitro expansion of HSC. Cellular fate is governed by cell-cell interaction with the microenvironment in the bone marrow, the stem cell niche. Mesenchymal stromal cells (MSC) are precursors of the cellular components, and they secrete extracellular matrix proteins of the bone marrow stroma. Therefore, MSC feeder layer might provide a suitable in vitro model system for the stem cell niche. In vitro assays demonstrate that MSC maintain the stem cell function of HSC and that MSC from bone marrow have a higher hematopoiesis supportive activity than MSC from adipose tissue. Cocultivation with MSC might pave the way for expansion of long-term repopulating $\mathrm{HSC}$, and various clinical trials indicate that co-transplantation of HSC and MSC might enhance engraftment. Thus, MSC are promising tools to elucidate the underlying mechanism of the cellular microenvironment. The large variety of preparative protocols for isolation and cultivation of MSC affects their stromal activity. Standardized isolation methods and molecular characterization of MSC are of utmost importance for reproducible isolation of hematopoiesis supportive stromal cells and for their potential clinical application.

\author{
Schlüsselwörter \\ Mesenchymale Stammzelle · Kultivierungsbedingungen · \\ Mikroenvironment · Differenzierung · \\ Hämatopoetische Stammzellen · Zell-Zell-Interaktion
}

\section{Zusammenfassung}

Die molekularen Mechanismen, die die Selbsterneuerung und Differenzierung von hämatopoetischen Stammzellen (hematopoietic stem cells; HSC) regulieren, sind von zentralem Interesse für die Stammzellbiologie und könnten langfristig die In-vitro-Expansion von HSC ermöglichen. Die Regulation der Stammzellfunktion erfolgt durch das zelluläre Milieu im Knochenmark, der sogenannten "Stammzellnische». Mesenchymale Stromazellen (mesenchymal stromal cells; MSC) stellen die Vorläufer für alle Zellkomponenten des Knochenmarkstromas dar und sezernieren Proteine der extrazellulären Matrix. Es liegt daher nahe, MSC als In-vitro-Modellsystem für die Stammzellnische zu verwenden. Tatsächlich belegen In-vitro-Assays, dass MSC die Stammzellfunktion von HSC erhalten, und dass MSC aus dem Knochenmark diese Funktion wesentlich besser erfüllen als MSC aus dem Fettgewebe. Zudem gibt es Hinweise, dass durch Kokultivierung von HSC mit MSC eine Expansion von primitiven HSC erreicht werden kann, und dass durch eine Kotransplantation von HSC mit MSC das hämatopoetische Engraftment gesteigert wird. MSC stellen somit vielversprechende Werkzeuge dar, um die regulativen Mechanismen der Stammzellnische zu untersuchen. Die Vielzahl der verwendeten Isolations- und Kultivierungsmethoden für MSC beeinflusst jedoch die isolierten MSC-Zellfraktionen und somit deren regulative Eigenschaften für HSC. Daher sind standardisierte Isolationsmethoden und eine molekulare Charakterisierung der MSC von zentraler Wichtigkeit für die reproduzierbare Isolation von supportiven Stromazellen und deren klinischen Einsatz.

\begin{tabular}{ll}
\hline KARGER & $\odot$ 2008 S. Karger GmbH, Freiburg \\
Fax +4976145207 14 & Accessible online at: \\
$\begin{array}{l}\text { E-mail Information@Karger.de } \\
\text { www.karger.com }\end{array}$ & www.karger.com/tmh
\end{tabular}

www.karger.com
Dr. Dr. Wolfgang Wagner

Department of Medicine V

University of Heidelberg,

Im Neuenheimer Feld 410, 69120 Heidelberg, Germany

Tel. +49 6221 56-6614, Fax -5813

E-mail wolfgang_wagner@med.uni-heidelberg.de 
Expansion of Hematopoietic Stem Cells - The Holy Grail

Stem cells are characterized by the dual ability to self-renew and to differentiate into cells of multiple lineages [1]. Transplantation of hematopoietic stem cells (HSC) is often limited by the availability of a suitable donor and by the amount of HSC in the graft. Mobilized peripheral blood stem cells (PBSC) have become the main source of autologous and allogeneic transplantation following myeloablative therapy in patients with hematological malignancies or solid tumors. Classical strategies for mobilization include administration of granulocyte colony stimulating factor (G-CSF). There are also new mobilizing strategies such as the CXCR4 antagonist AMD3100 which acts synergistically with G-CSF to mobilize more primitive HSC even in 'poor mobilizers' [2]. However, it is not always possible to harvest enough HSC for transplantation. The cell surface glycoprotein CD34 is used as a surrogate marker for HSC. The number of CD34+ cells infused correlates with the leukocyte and platelet recovery, and a threshold of $2-3 \times 10^{6} \mathrm{CD} 34+$ cells $/ \mathrm{kg}$ body weight seems to be necessary for secure engraftment upon transplantation [3]. The majority of CD34+ cells, however, comprise more committed progenitor cells, and HSC can be further enriched in the CD34+/CD38- cell fraction. Especially for umbilical cord blood transplantation in adults, the limited amount of available HSC provides the major restriction, resulting in delayed engraftment post-transplant, and both short- and long-term infectious complications. A reliable method for self-renewal under in vitro conditions that would allow expansion of longterm repopulating HSC is still elusive [4]. Finding a method for culture expansion of primitive HSC would be of high interest for stem cell biology and for clinical application. For more than 40 years, different culture media with combinations of cytokines have been tested, but so far ex vivo expansion of HSC has mainly resulted in expansion of mature progenitors rather than immature HSC, and it has failed to improve engraftment $[5,6]$. The mechanisms that regulate self-renewal and differentiation of adult stem cells are still unknown, but direct cell-cell interaction with the microenvironment, the stem cell niche, seems to play a central role in the regulation of stem cell function.

\section{Asymmetric Cell Division - Two Daughter Cells with Different Fate}

How can a single cell divide producing two progeny cells that adopt different fates? There is clear evidence that the different fate of daughter cells is determined in the course of cell division - a process called asymmetric cell division [7]. By monitoring the symmetry of divisions of HSC and following their subsequent developmental potentials at a single cell level, we have demonstrated a correlation between divisional kinetics and self-renewal capacity and gained insight into the mecha- nisms governing self-renewing asymmetric divisions of primitive HSC [8-10]. One daughter cell remained quiescent or divided very slowly while the other multiplied exponentially to yield committed progenitors and lineage-specific colonies. Asymmetric divisions are found significantly more often among CD34+/CD38- cells than in CD34+/CD38+ cells, and the percentage of asymmetric cell divisions was not affected by exposure to regulatory molecules [9]. A combination of monitoring of cell division history and of long-term culture revealed that slow or asymmetric cell division kinetics were associated with a significantly higher percentage of primitive cells giving rise to myeloid-lymphoid-initiating cells (ML-IC) $[11,12]$. We have exploited differences in division kinetics to separate the CD34+/CD38- cells into a more primitive, slowdividing fraction (SDF) and a committed, fast-dividing fraction (FDF). The SDF resembles a cell fraction that is highly polarized, forms many cell protrusions, and is actively migrating, whereas cells in the FDF were larger and less polarized [10]. Global gene expression profiles of these two populations were analyzed using a 'human transcriptome cDNA microarray'. Several molecular markers associated with primitive stem cell function are higher expressed in the SDF compared to the FDF $[10,13]$. Among the genes with the highest overexpression in the slow dividing stem cell fraction were Prominin (CD133), multiple drug resistance gene 1 (MDR1), complement component 1 receptor 1 (clqr1), as well as several transcription factors including the homeodomain proteins Hoxa9, Cdx1, and Hesx1. Thus, the observed differential gene expression in the self-renewing SDF and more committed FDF are consistent with the observation that slow and asymmetrically dividing cells among HSC indeed represent a functionally primitive, self-renewing population. Furthermore, it has been demonstrated that if the two daughter cells of slow dividing cells are separated by micromanipulation and analyzed individually, one daughter cell inherits the developmental capacity of the mother cell, whereas the other one becomes more specified [8]. This observation is compatible with asymmetric cell division in which one of the daughter cells retains the self-renewing capacity. Recently, Giebel et al. [14] described differential segregation of 4 proteins (CD53, CD62L/L-selectin, CD63/lamp-3, and CD71/transferrin receptor) in about $20 \%$ of primitive human hematopoietic cells that divide in stroma-free cultures. Further evidence for asymmetric cell division comes from other model organisms such as Drosophila melanogaster and Caenorhabditis elegans. Here, it has been demonstrated that asymmetric fate distribution to the daughter cells occurs upon polarization during cell division and localization of specific molecules to distinct regions of the cell [15]. The ultimate proof that the different fate of two hematopoietic daughter cells is determined during cytokinesis is still elusive, but these results indicate that asymmetric division holds also true for the hematopoietic system [7]. Either way, stem cell function has to be tightly controlled according to the physiological needs of the organism. 


\section{The Hematopoietic Stem Cell Niche}

Various intrinsic programs and pathways facilitate the unique characteristics of stem cells, and these programs - regulating maintenance, proliferation, and differentiation of HSC - have to be tightly controlled by the microenvironment [16]. In 1978, Schofield [17] proposed a hypothesis in which stem cells are seen in association with other cells which determine their behavior - the so called 'stem cell niche'. In adults, the hematopoietic stem cell niche is located in the bone marrow. The mechanism of this interaction of HSC with their local environment is largely unknown. In the murine model, specialized spindle-shaped N-cadherin-expressing osteoblasts (SNO) located in the endosteum have been postulated to play an essential role [18]. Osteoblastic cells seem to be a regulatory component of the hematopoietic stem cell niche that is activated by parathyroid hormone (PTH) and acts through Jagged1/ Notch activation [19]. For the human system, it is probable that other cell types such as osteoclasts, stromal cells, and endothelial cells, as well as the extracellular matrix, represent important components of the niche [20,21]. A primary function of the niche is to attract and to anchor stem cells. Various adhesion proteins including $\mathrm{N}$-cadherin and integrins as well as the distribution of stromal cell-derived factor- 1 seem to be important for this homing process [22,23]. The hematopoietic stem cell niche is preferentially located very close to the endosteal surface of the bone [24]. Analysis of the regulative mechanisms of the in vivo stem cell niche is limited by the complex composition of different cell types and by its location in the bone marrow. The use of defined cell populations as supportive feeder layer represents a suitable model system to understand the underlying mechanisms of the relevant cellcell interaction.

\section{Feeder Layer Cells Maintain Stem Cell Function in vitro}

In 1973, Dexter et al. [25] described that by co-cultivation of hematopoietic bone marrow cells with thymus cells, it was possible to maintain different stages of granulocytic cells for at least 10 weeks. These early experiments demonstrated that feeder layer cells may provide a supportive cellular environment to maintain primitive function of hematopoietic cells [26, 27]. The same mechanism of co-cultivation has also been used for other types of stem cells such as embryonic stem cells [28]. For the hematopoietic system, the potency of the feeder layer cell preparations is determined by functional assays such as colony-forming unit (CFU) assay, cobblestone area-forming cell (CAFC) assay, long-term culture-initiating cell (LTC-IC) assay or multilineage-initiating cell (ML-IC) assay [29]. These in vitro assays provide an estimate for the number and maintenance of primitive hematopoietic progenitor cells (HPC). Murine in vivo transplantation models such as competitive repopulation unit (CRU) assay or SCID-repopulating cell assays represent a more authentic test system for engraftment and differentiation potential, and the results do not necessarily correlate with the afore-mentioned in vitro assays [30]. On the other hand, these transplantation assays are very complex, the immune system of these mice is altered, and the mice may not adequately represent molecular characteristics of the human stem cell niche. Although numerous studies have demonstrated the vital role of stromal feeder layers for maintenance of multipotency of HPC in vitro, little is known about the precise cellular and molecular mechanisms of this interaction. Many 'stroma' cell preparations and cell lines, mostly derived from the bone marrow, have been demonstrated to serve as a feeder layer and to maintain HPC in an undifferentiated state with varying degrees of efficiency [31,32]. Cell lines have been created from the aorto-gonad-mesonephros region [33], fetal liver [31], and bone marrow [34, 35]. All of these tissues represent the hematopoietic stem cell niche during ontogeny of embryonic, fetal, and adult development. The cell lines were usually immortalized to circumvent cellular senescence. These studies have demonstrated significant differences in the hematopoietic supportive potential of different cell lines isolated from the same tissue. There have been attempts to characterize supportive and non-supportive cell lines and to gain insight into the molecular mechanisms of stromal feeder layer [36-40]. However, the molecular characteristics that govern the hematopoietic supportive potential are not revealed. Using human HPC (CD34+/CD38-) and a murine stromal cell line (AFT024) as a model, we have studied the initial behavioral and molecular sequel of this interaction [41]. Gene expression profiles of $\mathrm{CD} 34+/ \mathrm{CD} 38$ - cells upon cultivation with or without stroma for $16,20,48$, or $72 \mathrm{~h}$ were analyzed using our Human Genome cDNA Microarray. Among the first genes up-regulated within $16 \mathrm{~h}$ were Chk1, egr1, and cxcl2. Genes with the highest up-regulation throughout the time course included tubulin genes, ezrin, c1qr1, fos, pcna, mcm6, ung, and dnmt 1 . These results support the hypothesis that upon exposure to a cellular environment, regulation of cell division, re-organization of the cytoskeleton system, and maintenance of genetic stability and methylation patterns represent the most essential steps [41].

\section{Mesenchymal Stromal Cells - a Microenvironment Supporting Hematopoiesis}

Mesenchymal stromal cells (MSC) resemble plastic-adherent cell preparations isolated from bone marrow or other tissues that are positive for several antigens such as CD105, CD73, and CD90, that lack expression of hematopoietic antigens, and that are able to differentiate at least into osteoblasts, adipocytes, and chondroblasts under specific in vitro differentiating conditions $[42,43]$. Alternatively, these cell preparations have been termed 'mesenchymal stem cells' using the same acronym. It is commonly accepted that a rare bona fide 
mesenchymal stem cell population exists, but there is also evidence that the adherent cell populations are very heterogeneous comprising only a small subset of stem cells. Therefore, it has been suggested to clarify the terminology of these fibroblast-like plastic adherent cells by calling them 'mesenchymal stromal cells' [44, 45]. This terminology also reflects their hematopoiesis supportive function as stromal feeder layer (fig. 1).

Since MSC are ubiquitous in the human bone marrow and generate osteoblasts, fibroblasts, and osteoclasts - all cells constituting the marrow niche - they could provide an excellent surrogate model in vitro to define the relative roles of various homing and adhesion pathways [46, 47]. Muguruma et al. [48] have shown that MSC were able to reconstitute the complete human bone marrow environment in irradiated mice upon intramedullary transplantation of enhanced green fluorescent protein-marked human MSC. The presence of human MSC in murine bone marrow resulted in an increase in functionally and phenotypically primitive human hematopoietic cells, and these results indicate functional differences in the human and murine hematopoietic stem cell niche. MSC have also been demonstrated to maintain primitive function of hematopoietic progenitor cells in vitro $[46,47,49,50]$. We have demonstrated that MSC from bone marrow establish more adhesive cellcell interaction with HPC, and maintain more primitive CD34+/CD38- immunophenotype and more LTC-IC function in comparison to a fibroblast cell line [39]. In comparison to immortalized murine stromal cell lines, human MSC preparations have the advantage of no-cross species variation for co-culture with human HSC. These cell preparations can be readily expanded without immortalization of the cell preparation, and they could theoretically be used in an isogenic setting using stroma cells and HSC of the same donor. As an in vitro model for the stem cell niche, MSC from bone marrow have the advantage to be isolated from the same natural stem cell niche as HSC. Furthermore, MSC are believed to facilitate the engraftment of HSC when transplanted simultaneously. They have been shown to promote engraftment in immunodeficient mice and fetal sheep, and support reconstitution of myeloid, lymphoid, and megakaryocytic lineages [51-53]. The feasibility of this method has already been tested in human trials [54-56]. These results demonstrate that the stromal activity of MSC represents an important functional aspect with potential clinical applications.

\section{The Many Facets of Menchymal Stem Cell Preparations}

The use of MSC is hampered by the lack of standardized preparation methods and of reliable molecular markers [57]. MSC can be derived from different tissues as starting material by diverse isolation protocols. They can be cultured and expanded in different media and conditions. Thus, MSC preparations from different laboratories are highly heterogeneous. All
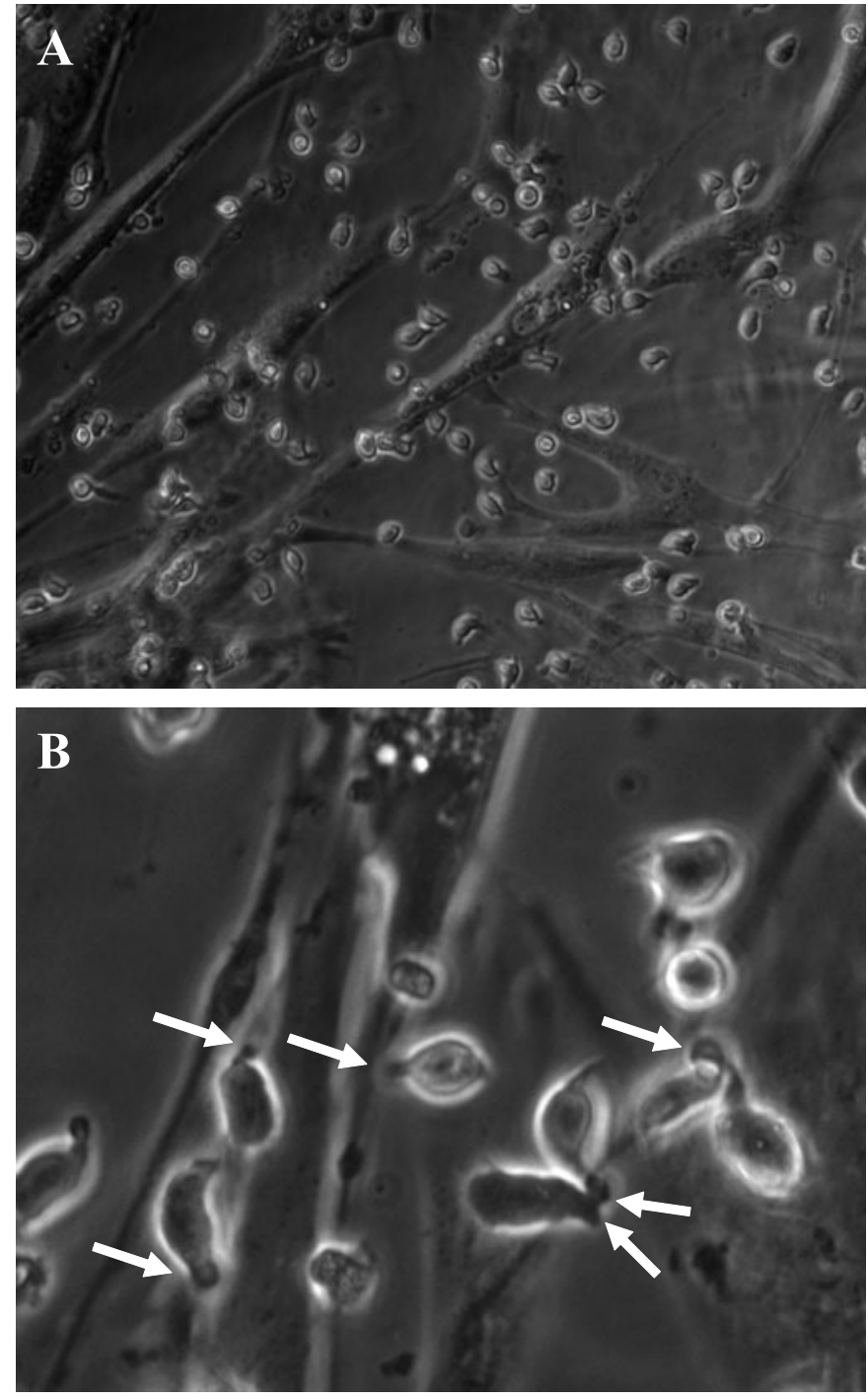

Fig. 1. Interaction of $\mathrm{HPC}$ and MSC. Human CD34+ HPC are cultivated on human MSC from bone marrow (HPC: small, round shaped cells; MSC: large, spindle shaped cells). Phase contrast microscopic analysis demonstrates that the majority of cells is in direct cell-cell contact with the feeder layer cells (A 20× objective). Most of the HPC are highly polarized and adhere to the MSC with their uropod at the trailing edge (B uropod is indicated by white arrows; $60 \times$ objective).

of these variables might have implications: i) they can effect the selection of cell types and the composition of heterogeneous sub-populations; ii) they can selectively favor expansion of different cell populations with totally different potentials; or iii) they might alter the long-term fate of adult stem cells upon in vitro culture [57]. To analyze functional implications of MSC preparations on their stromal activity, we have isolated MSC from human bone marrow, cord blood, and adipose tissue. Adhesion of HPC and maintenance of a primitive CD34+/CD38- immunophenotype was significantly higher on MSC from bone marrow and cord blood in comparison to MSC from adipose tissue. When we used these stromal feeder cells for long-term co-culture experiments, the LTC-IC frequency was also significantly lower on MSC from adipose tis- 


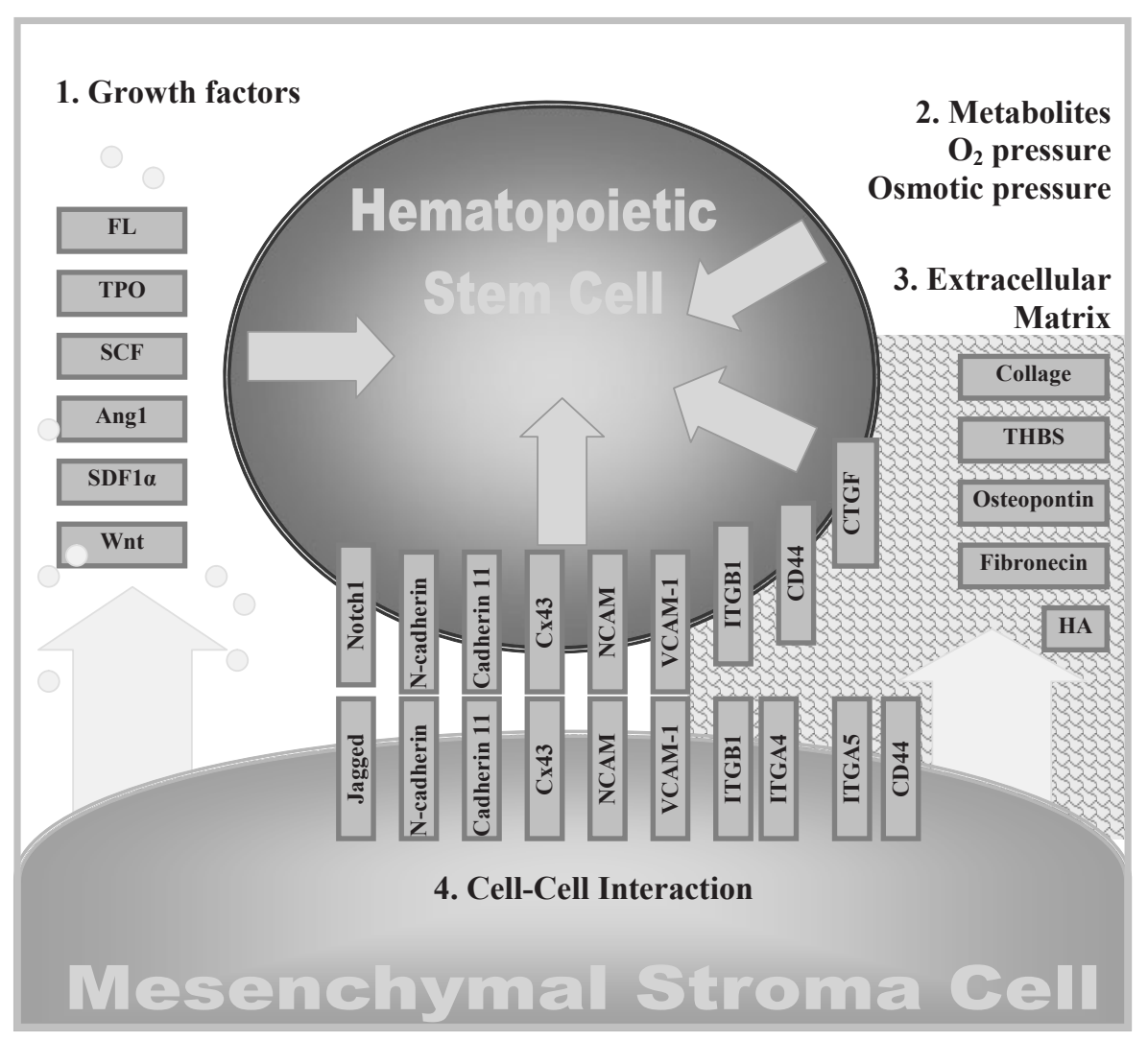

Fig. 2. Molecular mechanisms of hematopoiesis supportive stromal feeder layer. MSC maintain primitive function of HPC. The molecular mechanism of this hematopoietic supportive interaction might be mediated by 1 ) growth factors, 2) metabolites and oxygen tension,

3) extracellular matrix components, and

4) direct cell-cell junctions. Various proteins that seem to be involved in this interaction are indicated in this figure and discussed in the text.

sue [39]. These findings demonstrate that there are functional differences between MSC preparations from different tissues in their hematopoietic supportive function. These functional differences between MSC pave the way for comparative studies to investigate the molecular mechanisms that regulate asymmetric cell division in HSC [7].

\section{Molecular Mechanisms of Stromal Cells}

MSC maintain stem cell function of HSC, but the molecular mechanism of this interaction is hardly unraveled. In theory, 4 independent mechanism might be involved in the supportive function: i) soluble chemokines and growth factors are secreted by MSC; ii) metabolites and oxygen tension are modified; iii) extracellular matrix components secreted by MSC build a scaffold for HSC; and iv) direct cell-cell interaction can be established between MSC and HSC. Most likely, all of these mechanisms work together in an orchestra of factors to regulate stem cell function (fig. 2).

\section{Chemokines and Growth Factors}

More than 40 years of intensive research with focus on culture conditions and chemokines for in vitro cultivation of HSC have demonstrated a crucial role of growth factors. Various growth factors have been analyzed in a huge variety of combinations. Stem cell factor (SCF), Flt-3 ligand (FL), and thrombopoietin (TPO) seem to play a central role, and are often added to co-cultures with stromal cells [58]. MSC secrete a variety of cytokines and growth factors that have both paracrine and autocrine activities [59]. For MSC, analysis of secretory profiles is of specific relevance, as secreted molecules might act via direct and indirect effects: direct effects on the MSC themselves, indirectly by inducing other cells in the vicinity to alter their biological properties and functions. The latter mechanism might explain some of the positive therapeutic effects observed with MSC without any evidence of 'trans-differentiation' of MSC. For example, such indirect effects have been proposed in treatment of stroke, myocardial infarction, and meniscus repair [59]. Chemokine secretion of the stromal feeder layer cells might also account for the hematopoiesis supportive effect of MSC. We have studied the cytokine production of MSC that have been isolated from bone marrow, cord blood, and adipose tissue by cytokine antibody arrays, ELISA, and a cytometric bead array [39]. IL-6, IL-8, MCP1, GCSF, GRO, TIMP-1, and TIMP-2 were highly expressed in all of these MSC, and there was a lower constitutive expression for various other cytokines. Hierarchical cluster analysis of the cytokine antibody arrays revealed that there were reproducible differences in the chemokine secretion profiles of MSC isolated under different conditions, but there was no clear concordance with differences in their potential to maintain primitive function of HPC. Only IGFBP-1 and -2 were higher expressed in feeder layer that maintained primitive function of HPC. We have performed additional experiments to address the functional role if IGFBPs. Neither IGFBP-1, 
IGFBP-2, nor IGFBP-3 had an effect on proliferation or maintenance of a primitive immunophenotype of HPC [39].

Many groups including our group have demonstrated that HSC can not be maintained in conditioned culture medium of feeder layer cells under non-contact conditions [11, 47, 60]. Although studies of other groups have suggested that primitive function of HPC might also be preserved in a transwell setting $[40,61]$, there is evidence that soluble molecules alone are not enough to maintain long-term repopulating potential. This is also reflected by the absence of reliable protocols for maintenance or expansion of HSC without stromal cell support.

\section{Metabolites and Oxygen Tension}

Small molecules such as hormones or metabolites are also secreted by the stromal feeder layer cells, and it is possible that these compounds are also involved in the hematopoiesis supportive function. For example serotonin, a monoamine neurotransmitter, has been implicated in maintenance and regulation of HSC function [62]. Glucose concentration and metabolites such as lactate can also be affected by stromal feeder cells. Furthermore, oxygen partial pressure has been demonstrated to play an important role as well. Culture methods with lower oxygen concentration confirmed that an $\mathrm{O}_{2}$ content of $3 \%$ or less enhances colony-forming cell expansion and maintenance of SCID-repopulating cells [63]. The influence of MSC on the composition of metabolites in their local microenvironment is hardly known. Further research is necessary to elucidate the role of metabolites in the regulation of stem cell function.

\section{Extracellular Matrix}

Mesenchymal stromal cells secrete extracellular matrix proteins that form a scaffold with a potential pivotal role in homing and differentiation of HSC. It has been demonstrated that collagen types I, IV, and fibronectin are localized to the endosteum, the region of the femoral microenvironment for which homing stem cells have a high affinity [64]. Furthermore, laminin and various proteoglycans reside in the bone marrow, and their functional implication in maintenance of stem cell function has been examined in various studies. Protein-coated surfaces with fibronectin [65], laminin [66], and large-size Osulfated heparan sulfate glycosaminoglycans [67] have been demonstrated to support maintenance of primitive HPC. Furthermore, Oswald et al. [68] have used a bioartificial matrix of fibrillar collagen I, the major matrix component of bone, as a scaffold for ex vivo expansion of HSC. Extracellular matrix components can also bind soluble factors and thereby present them in the biologically active form to HSC [69]. Osteopontin, a matrix glycoprotein, has also been demonstrated to play a role in the hematopoietic stem cell niche [70]. These extracellular matrix components are also secreted by MSC feeder layer cells and they may constitute a relevant component for the artificial 'in vitro stem cell niche'. We have demonstrated that CD34+ HPC are interwoven in a fibronectin network se- creted by MSC [71]. Interaction of HPC with MSC is also indicated by the reduced adhesion upon treatment with an antibody blocking the function of CD44, a receptor for hyaluronic acid and other extracellular matrix components [71]. We have also demonstrated that by applying a $\beta_{1}$-integrin functionblocking antibody, adhesion between HSC and MSC is significantly impaired [46], as well as the regulation of the long-term fate of HSC. Treatment of HSC with this monoclonal anti- $\beta_{1-}$ integrin antibody induced a significant reduction in the proportion of self-renewing divisions and yield of LTC-IC [47].

\section{Cell-Cell Interaction}

The essential role of direct cell-cell contact for the regulation of self-renewal and differentiation of adult stem cells has been shown in various organisms and cell systems. Specific junctional complexes may play a similar role in the hematopoietic system [1]. HPC subsets with higher self-renewing capacity demonstrated significantly higher adhesion to human MSC (CD34+ vs. CD34-, CD34+/CD38- vs. CD34+/CD38+, slow dividing fraction vs. fast dividing fraction) [46]. Functional implications have been described for a number of proteins such as $\mathrm{N}$-cadherin for homing and adhesion of HSC to the bone marrow niche in animal models $[18,72]$. In contrast, studies on the interactions between human HSC and the niche of the same species are rare. Human MSC provide a suitable model system for such studies. We have analyzed gene expression profiles of adherent and non-adherent HPC as well as of adhesive and non-adhesive MSC $[39,46]$. Genes that were up-regulated on both sides of the heterotypic HPC/MSC interaction included cadherin-11, N-cadherin, integrin alpha-1 (ITGA1), alpha-5 (ITGA5, CD49e) and beta-1 (ITGB1, CD29), VCAM1, NCAM1, and thrombospondin 1 (THBS1). Thus, corresponding adhesion molecules are highly expressed in adhesive feeder layer cells as well as in the adherent fraction of HPC. These results imply that molecular mechanisms essential in maintenance of 'stemness' are mediated by a combination of cellcell junction proteins (including cadherin-11, N-cadherin, NCAM1, VCAM1). Further studies are necessary to determine the relative significance of these cell adhesion proteins.

\section{Mesenchymal Stem Cell Influence on Migration and Podia Formation in HPC}

HPC are characterized by rapid migratory activity and constantly changing morphology [73, 74]. They actively migrate towards stromal cells and extend magnupodia in the direction of the latter [75]. Several authors have reported the significance of podia formation for migration of HPC and subsequently for the cell-cell contact between HPC and cellular elements in the niche [75-77]. In previous reports we have described various types of podia in CD34+, CD34+/CD38- and in the slow dividing fraction of CD34+/CD38- cells [10, 73]. These different morphological types of pseudopodia might be 
associated with specific functions including communication, adhesion, and homing to specific sites in the microenvironment. We have demonstrated that HPC migrate towards supportive stromal cells and subsequently establish stable contact with their uropod at the trailing edge [41]. These results indicated that HPC migrate towards specific signals secreted by feeder layer cells. We have not been able to characterize these signals yet. It is likely that stromal cell derived factor-1 (SDF1 ), a potent chemo-attractant, plays an important role in this process. However, direct contact through extremely elongated podia of up to $300 \mu \mathrm{m}$ from HPC might also guide the way of HPC [77]. Adhesion of HPC is mediated by the trailing edge, whereas rapidly extended proteopodia at the leading edge get in touch with surrounding stromal cells, possibly searching for a more suitable environment. These observations indicate that directed movement is initiated along this axis, and a series of adhesive interactions may guide HPC to their niche in the bone marrow [18, 19, 78, 79].

\section{Outlook}

Self-renewal and differentiation of HSC has to be tightly regulated by the stem cell niche in the bone marrow. MSC are precursors of the cellular components of the bone marrow stroma, and they secrete corresponding extracellular matrix components. In vitro assays indicate that they maintain primitive function of HSC, and there is evidence that co-cultivation with MSC might be used for expansion of HSC. There are various clinical trials that indicate that co-transplantation of HSC and MSC might enhance engraftment. In a recent pilot study, Le Blanc et al. [54] have reported the use of allogeneic MSC to enhance engraftment in 7 patients. Co-transplantation of MSC resulted in a fast engraftment even in 3 patients that were re- transplanted for graft failure or rejection. However, the mechanisms that enhance hematopoietic recovery remain unclear as after hematopoietic stem cell transplantation the stromal progenitors are predominantly of recipient origin [80]. Further studies are necessary to substantiate the beneficial effect of co-transplantation with MSC and to elucidate the biological mechanism. As MSC are not immortalized and become senescent after 8-15 passages, they need to be repeatedly isolated. There is a huge arsenal of isolation methods and culture conditions for MSC preparations. These isolation conditions have a high impact on the cellular composition and the molecular profile of the isolated cell preparations, and they also affect the hematopoiesis supportive activity of MSC [57]. We have provided clear evidence that MSC from adipose tissue do not maintain primitive function of HPC in comparison to MSC from bone marrow [39]. These results indicate that there are significant differences in MSC preparations despite similar cell morphology, immunophenotype, and in vitro differentiation potential. Standardized isolation methods and molecular characterization of MSC are of ultimate importance for reproducible isolation of hematopoiesis supportive stromal cells and for potential clinical application. On the other hand, comparative studies of hematopoiesis supportive and non-supportive feeder layer cells can shed light on the underlying mechanisms of the regulating cellular microenvironment.

\section{Acknowledgement}

This work was supported by the German Ministry of Education and Research (BMBF) within the National Genome Research Network NGFN-2 (EP-S19T01) and within the supporting program 'cell based regenerative medicine' (START-MSC), the German Research Foundation DFG (HO 914/7-1), the Joachim Siebeneicher-Stiftung, and the Academy of Sciences and Humanities, Heidelberg (WIN-Kolleg).

\section{References}

$\checkmark 1$ Ho AD: Kinetics and symmetry of divisions of hematopoietic stem cells. Exp Hematol 2005;33:1-8.

$\checkmark 2$ Fruehauf S, Seeger T: New strategies for mobilization of hematopoietic stem cells. Future Onco 2005; $1: 375-83$.

3 Klaus J, Herrmann D, Breitkreutz I, Hegenbart U, Mazitschek U, Egerer G, Cremer FW, Lowenthal RM, Huesing J, Fruehauf S, Moehler T, Ho AD, Goldschmidt H: Effect of CD34 cell dose on hematopoietic reconstitution and outcome in 508 patients with multiple myeloma undergoing autologous peripheral blood stem cell transplantation. Eur J Haematol 2007;78:21-8.

4 Hofmeister CC, Zhang J, Knight KL, Le P, Stiff PJ: Ex vivo expansion of umbilical cord blood stem cells for transplantation: growing knowledge from the hematopoietic niche. Bone Marrow Transplant 2007;39:11-23.

$>5$ Rice A, Flemming C, Case J, Stevenson J, Gaudry L, Vowels M: Comparative study of the in vitro behavior of cord blood subpopulations after shortterm cytokine exposure. Bone Marrow Transplant 1999;23:211-20.
6 6 McNiece IK, Almeida-Porada G, Shpall EJ, Zanjani E: Ex vivo expanded cord blood cells provide rapid engraftment in fetal sheep but lack long-term engrafting potential. Exp Hematol 2002;30:612-6.

7 Ho AD, Wagner W: The beauty of asymmetry asymmetric divisions and self-renewal in the hematopoietic system. Curr Opin Hematol 2007;14:330-6.

8 Giebel B, Zhang T, Beckmann J, Spanholtz J, Wernet $\mathrm{P}$, Ho AD, Punzel M: Primitive human hematopoietic cells give rise to differentially specified daughter cells upon their initial cell division. Blood 2006;107:2146-52.

$\checkmark 9$ Huang S, Law P, Francis K, Palsson BO, Ho AD: Symmetry of initial cell divisions among primitive hematopoietic progenitors is independent of ontogenic age and regulatory molecules. Blood 1999;94: 2595-604.

10 Wagner W, Ansorge A, Wirkner U, Eckstein V, Schwager C, Blake J, Miesala K, Selig J, Saffrich R, Ansorge W, Ho AD: Molecular evidence for stem cell function of the slow-dividing fraction among human hematopoietic progenitor cells by genomewide analysis. Blood 2004;104:675-86.
11 Punzel M, Liu D, Zhang T, Eckstein V, Miesala K, Ho AD: The symmetry of initial divisions of human hematopoietic progenitors is altered only by the cellular microenvironment. Exp Hematol 2003;31: 339-47.

12 Punzel M, Zhang T, Liu D, Eckstein V, Ho AD: Functional analysis of initial cell divisions defines the subsequent fate of individual human CD34 (+)CD38(-) cells. Exp Hematol 2002;30:464-72.

13 Wagner W, Laufs S, Blake J, Schwager C, Wu X, Zeller JW, Ho AD, Fruehauf S: Retroviral integration sites correlate with expressed genes in hematopoietic stem cells. Stem Cells 2005;23:1050-8.

14 Beckmann J, Scheitza S, Wernet P, Fischer JC, Giebel B: Asymmetric cell division within the human hematopoietic stem and progenitor cell compartment: identification of asymmetrically segregating proteins. Blood 2007;109:5494-501.

15 Betschinger J, Knoblich JA: Dare to be different: asymmetric cell division in Drosophila, C. elegans and vertebrates. Curr Biol 2004;14:R674-R685. 
16 Moore KA, Lemischka IR: Stem cells and their niches. Science 2006;311:1880-5.

17 Schofield R: The relationship between the spleen colony-forming cell and the haemopoietic stem cell. Blood Cells 1978;4:7-25.

18 Zhang J, Niu C, Ye L, Huang H, He X, Tong WG, Ross J, Haug J, Johnson T, Feng JQ, Harris S, Wiedemann LM, Mishina Y, Li L: Identification of the haematopoietic stem cell niche and control of the niche size. Nature 2003;425:836-41.

19 Calvi LM, Adams GB, Weibrecht KW, Weber JM, Olson DP, Knight MC, Martin RP, Schipani E, Divieti P, Bringhurst FR, Milner LA, Kronenberg HM, Scadden DT: Osteoblastic cells regulate the haematopoietic stem cell niche. Nature 2003;425: 841-6.

20 Wilson A, Trumpp A: Bone-marrow haematopoietic-stem-cell niches. Nat Rev Immunol 2006;6:93106.

21 Forsberg EC, Prohaska SS, Katzman S, Heffner GC, Stuart JM, Weissman IL: Differential expression of novel potential regulators in hematopoietic stem cells. PLoS Genet 2005;1:e28.

-22 Dar A, Goichberg P, Shinder V, Kalinkovich A, Kollet O, Netzer N, Margalit R, Zsak M, Nagler A Hardan I, Resnick I, Rot A, Lapidot T: Chemokine receptor CXCR4-dependent internalization and resecretion of functional chemokine SDF-1 by bone marrow endothelial and stromal cells. Nat Immunol 2005;6:1038-46.

23 Papayannopoulou T, Nakamoto B: Peripheralization of hemopoietic progenitors in primates treated with anti-VLA4 integrin. Proc Natl Acad Sci U S A 1993;90:9374-8

24 Adams GB, Scadden DT: The hematopoietic stem cell in its place. Nat Immunol 2006;7:333-7.

25 Dexter TM, Allen TD, Lajtha LG, Schofield R, Lord BI: Stimulation of differentiation and proliferation of haemopoietic cells in vitro. J Cell Physiol 1973;82:461-73.

26 Dexter TM, Wright EG, Krizsa F, Lajtha LG: Regulation of haemopoietic stem cell proliferation in long term bone marrow cultures. Biomedicine 1977; 27:344-9.

27 Dexter TM: Haemopoiesis in long-term bone marrow cultures. A review. Acta Haematol 1979;62: 299-305.

28 Shamblott MJ, Axelman J, Wang S, Bugg EM, Littlefield JW, Donovan PJ, Blumenthal PD, Huggins GR, Gearhart JD: Derivation of pluripotent stem cells from cultured human primordial germ cells. Proc Natl Acad Sci U S A 1998;95:13726-31.

29 De Wynter E, Ploemacher RE: Assays for the assessment of human hematopoietic stem cells. J Biol Regul Homeost Agents 2001;15:23-7.

\$3 Gan OI, Murdoch B, Larochelle A, Dick JE: Differential maintenance of primitive human SCID-repopulating cells, clonogenic progenitors, and long-term culture-initiating cells after incubation on human bone marrow stromal cells. Blood 1997;90:641-50

>31 Wineman J, Moore K, Lemischka I, Muller-Sieburg C: Functional heterogeneity of the hematopoietic microenvironment: rare stromal elements maintain long-term repopulating stem cells. Blood 1996;87: 4082-90.

\32 Wineman JP, Nishikawa S, Muller-Sieburg CE: Maintenance of high levels of pluripotent hematopoietic stem cells in vitro: effect of stromal cells and c-kit. Blood 1993;81:365-72.

\$3 Ohneda O, Fennie C, Zheng Z, Donahue C, La H, Villacorta R, Cairns B, Lasky LA: Hematopoietic stem cell maintenance and differentiation are supported by embryonic aorta-gonad-mesonephros region-derived endothelium. Blood 1998;92:908-19.
34 Collins LS, Dorshkind K: A stromal cell line from myeloid long-term bone marrow cultures can support myelopoiesis and B lymphopoiesis. J Immunol 1987;138:1082-7.

35 Itoh K, Tezuka H, Sakoda H, Konno M, Nagata K, Uchiyama T, Uchino H, Mori KJ: Reproducible establishment of hemopoietic supportive stromal cell lines from murine bone marrow. Exp Hematol 1989;17:145-53.

36 Charbord P, Moore K: Gene expression in stem cell-supporting stromal cell lines. Ann N Y Acad Sci 2005;1044:159-67.

37 Hackney JA, Charbord P, Brunk BP, Stoeckert CJ, Lemischka IR, Moore KA: A molecular profile of a hematopoietic stem cell niche. Proc Natl Acad Sci U S A 2002;99:13061-6.

38 Weisel KC, Gao Y, Shieh JH, Moore MA: Stromal cell lines from the aorta-gonado-mesonephros region are potent supporters of murine and human hematopoiesis. Exp Hematol 2006;34:1505-16.

39 Wagner W, Roderburg C, Wein F, Diehlmann A, Frankhauser M, Schubert R, Eckstein V, Ho AD: Molecular and secretory profiles of human mesenchymal stromal cells and their abilities to maintain primitive hematopoietic progenitors. Stem Cells 2007;25:2638-47.

40 Oostendorp RA, Robin C, Steinhoff C, Marz S, Brauer R, Nuber UA, Dzierzak EA, Peschel C: Long-term maintenance of hematopoietic stem cells does not require contact with embryo-derived stromal cells in cocultures. Stem Cells 2005;23:84251.

41 Wagner W, Saffrich R, Wirkner U, Eckstein V, Blake J, Ansorge A, Schwager C, Wein F, Miesala $\mathrm{K}$, Ansorge W, Ho AD: Hematopoietic progenitor cells and cellular microenvironment: behavioral and molecular changes upon interaction. Stem Cells 2005;23:1180-91.

42 Dominici M, Le Blanc K, Mueller I, Slaper-Cortenbach I, Marini F, Krause D, Deans R, Keating A, Prockop D, Horwitz E: Minimal criteria for defining multipotent mesenchymal stromal cells. The International Society for Cellular Therapy position statement. Cytotherapy 2006;8:315-7.

43 Wagner W, Wein F, Seckinger A, Frankhauser M, Wirkner U, Krause U, Blake J, Schwager C, Eckstein V, Ansorge W, Ho AD: Comparative characteristics of mesenchymal stem cells from human bone marrow, adipose tissue, and umbilical cord blood. Exp Hematol 2005;33:1402-16.

44 Horwitz EM, Keating A: Nonhematopoietic mesenchymal stem cells: what are they? Cytotherapy 2000;2:387-8.

45 Horwitz EM, Le BK, Dominici M, Mueller I, Slaper-Cortenbach I, Marini FC, Deans RJ, Krause DS, Keating A: Clarification of the nomenclature for MSC: The International Society for Cellular Therapy position statement. Cytotherapy 2005;7: 393-5.

46 Wagner W, Wein F, Roderburg C, Saffrich R, Faber A, Krause U, Schubert M, Benes V, Eckstein V, Maul H, Ho AD: Adhesion of hematopoietic progenitor cells to human mesenchymal stem cells as a model for cell-cell interaction. Exp Hematol 2007; 35:314-25.

47 Gottschling S, Saffrich R, Seckinger A, Krause U, Horsch K, Miesala K, Ho AD: Human mesenchymal stroma cells regulate initial self-renewing divisions of hematopoietic progenitor cells by a beta1integrin-dependent mechanism. Stem Cells 2007;25: 798-806.
48 Muguruma Y, Yahata T, Miyatake H, Sato T, Uno T, Itoh J, Kato S, Ito M, Hotta T, Ando K: Reconstitution of the functional human hematopoietic microenvironment derived from human mesenchymal stem cells in the murine bone marrow compartment. Blood 2006;107:1878-87.

49 Jang YK, Jung DH, Jung MH, Kim DH, Yoo KH, Sung KW, Koo HH, Oh W, Yang YS, Yang SE: Mesenchymal stem cells feeder layer from human umbilical cord blood for ex vivo expanded growth and proliferation of hematopoietic progenitor cells. Ann Hematol 2006;85:212-25.

50 Robinson SN, Ng J, Niu T, Yang H, McMannis JD, Karandish S, Kaur I, Fu P, Del AM, Messinger R, Flagge F, de LM, Decker W, Xing D, Champlin R, Shpall EJ: Superior ex vivo cord blood expansion following co-culture with bone marrow-derived mesenchymal stem cells. Bone Marrow Transplant 2006;37:359-66.

51 Almeida-Porada G, Porada CD, Tran N, Zanjani ED: Cotransplantation of human stromal cell progenitors into preimmune fetal sheep results in early appearance of human donor cells in circulation and boosts cell levels in bone marrow at later time points after transplantation. Blood 2000;95:3620-7.

52 Angelopoulou M, Novelli E, Grove JE, Rinder HM, Civin C, Cheng L, Krause DS: Cotransplantation of human mesenchymal stem cells enhances human myelopoiesis and megakaryocytopoiesis in NOD/SCID mice. Exp Hematol 2003;31:413-20.

53 Kim DW, Chung YJ, Kim TG, Kim YL, Oh IH Cotransplantation of third-party mesenchymal stromal cells can alleviate single-donor predominance and increase engraftment from double cord transplantation. Blood 2004;103:1941-8.

54 Le Blanc K, Samuelsson H, Gustafsson B, Remberger M, Sundberg B, Arvidson J, Ljungman P, Lonnies H, Nava S, Ringden O: Transplantation of mesenchymal stem cells to enhance engraftment of hematopoietic stem cells. Leukemia 2007;21:1733-8.

55 Lazarus HM, Koc ON, Devine SM, Curtin P, Maziarz RT, Holland HK, Shpall EJ, McCarthy P, Atkinson K, Cooper BW, Gerson SL, Laughlin MJ, Loberiza FR Jr, Moseley AB, Bacigalupo A: Cotransplantation of HLA-identical sibling cultureexpanded mesenchymal stem cells and hematopoietic stem cells in hematologic malignancy patients. Biol Blood Marrow Transplant 2005;11:389-98.

56 Koc ON, Gerson SL, Cooper BW, Dyhouse SM, Haynesworth SE, Caplan AI, Lazarus HM: Rapid hematopoietic recovery after coinfusion of autologous-blood stem cells and culture-expanded marrow mesenchymal stem cells in advanced breast cancer patients receiving high-dose chemotherapy. J Clin Oncol 2000;18:307-16.

57 Wagner W, Ho AD: Mesenchymal stem cell preparations - comparing apples and oranges. Stem Cell Rev 2007;3:239-48.

58 Yoshikubo T, Inoue T, Noguchi M, Okabe H: Differentiation and maintenance of mast cells from CD34(+) human cord blood cells. Exp Hematol 2006;34:320-9.

59 Caplan AI, Dennis JE: Mesenchymal stem cells as trophic mediators. J Cell Biochem 2006;98:1076-84.

60 Kanai M, Hirayama F, Yamaguchi M, Ohkawara J, Sato N, Fukazawa K, Yamashita K, Kuwabara M, Ikeda H, Ikebuchi K: Stromal cell-dependent ex vivo expansion of human cord blood progenitors and augmentation of transplantable stem cell activity. Bone Marrow Transplant 2000;26:837-44.

61 Kogler G, Radke TF, Lefort A, Sensken S, Fischer J, Sorg RV, Wernet P: Cytokine production and hematopoiesis supporting activity of cord bloodderived unrestricted somatic stem cells. Exp Hematol 2005;33:573-83. 
62 Yang M, Li K, Ng PC, Chuen CK, Lau TK, Cheng YS, Liu YS, Li CK, Yuen PM, James AE, Lee SM, Fok TF: Promoting effects of serotonin on hematopoiesis: ex vivo expansion of cord blood CD34+ stem/progenitor cells, proliferation of bone marrow stromal cells, and antiapoptosis. Stem Cells 2007;25: $1800-6$.

-63 Ivanovic Z, Hermitte F, Brunet dlG, Dazey B Belloc F, Lacombe F, Vezon G, Praloran V: Simultaneous maintenance of human cord blood SCID repopulating cells and expansion of committed progenitors at low $\mathrm{O} 2$ concentration $(3 \%)$. Stem Cells 2004;22:716-24.

64 Nilsson SK, Debatis ME, Dooner MS, Madri JA, Quesenberry PJ, Becker PS: Immunofluorescence characterization of key extracellular matrix proteins in murine bone marrow in situ. J Histochem Cytochem 1998;46:371-7.

65 Dao MA, Hashino K, Kato I, Nolta JA: Adhesion to fibronectin maintains regenerative capacity during ex vivo culture and transduction of human hematopoietic stem and progenitor cells. Blood 1998;92:4612-21.

-66 Sagar BM, Rentala S, Gopal PN, Sharma S, Mukhopadhyay A: Fibronectin and laminin enhance engraftibility of cultured hematopoietic stem cells. Biochem Biophys Res Commun 2006;350: 1000-5.

67 Punzel M, Gupta P, Verfaillie CM: The microenvironment of AFT024 cells maintains primitive human hematopoiesis by counteracting contact mediated inhibition of proliferation. Cell Commun Adhes 2002;9:149-59.
68 Oswald J, Steudel C, Salchert K, Joergensen B, Thiede C, Ehninger G, Werner C, Bornhauser M: Gene-expression profiling of CD34+ hematopoietic cells expanded in a collagen I matrix. Stem Cells 2006;24:494-500.

69 Roberts R, Gallagher J, Spooncer E, Allen TD, Bloomfield F, Dexter TM: Heparan sulphate bound growth factors: a mechanism for stromal cell mediated haemopoiesis. Nature 1988;332:376-8.

70 Stier S, Ko Y, Forkert R, Lutz C, Neuhaus T, Grunewald E, Cheng T, Dombkowski D, Calvi LM, Rittling SR, Scadden DT: Osteopontin is a hematopoietic stem cell niche component that negatively regulates stem cell pool size. J Exp Med 2005;201: 1781-91.

71 Wagner W, Wein F, Roderburg C, Saffrich R, Diehmann A, Eckstein V, Ho AD: Adhesion of human hematopoietic progenitor cells to mesenchymal stromal cells involves CD44. Cells Tissues Organs 2007; DOI: $\underline{10.1159 / 000112821}$

72 Puch S, Armeanu S, Kibler C, Johnson KR, Muller CA, Wheelock MJ, Klein G: N-cadherin is developmentally regulated and functionally involved in early hematopoietic cell differentiation. J Cell Sci 2001;114:1567-77.

73 Fruehauf S, Srbic K, Seggewiss R, Topaly J, Ho AD: Functional characterization of podia formation in normal and malignant hematopoietic cells. J Leukoc Biol 2002;71:425-32.

74 Giebel B, Corbeil D, Beckmann J, Hohn J, Freund D, Giesen K, Fischer J, Kogler G, Wernet P: Segregation of lipid raft markers including CD133 in polarized human hematopoietic stem and progenitor cells. Blood 2004;104:2332-8.
75 Frimberger AE, McAuliffe CI, Werme KA, Tuft RA, Fogarty KE, Benoit BO, Dooner MS, Quesenberry PJ: The fleet feet of haematopoietic stem cells: rapid motility, interaction and proteopodia. $\mathrm{Br}$ J Haematol 2001;112:644-54.

76 Holloway W, Martinez AR, Oh DJ, Francis K, Ramakrishna R, Palsson BO: Key adhesion molecules are present on long podia extended by hematopoietic cells. Cytometry 1999;37:171-7.

77 Francis K, Ramakrishna R, Holloway W, Palsson BO: Two new pseudopod morphologies displayed by the human hematopoietic KG1a progenitor cell line and by primary human CD34(+) cells. Blood 1998;92:3616-23.

78 Arai F, Hirao A, Ohmura M, Sato H, Matsuoka S, Takubo K, Ito K, Koh GY, Suda T: Tie2/angiopoietin-1 signaling regulates hematopoietic stem cell quiescence in the bone marrow niche. Cell 2004;118:149-61.

79 Quesenberry PJ, Colvin G, Abedi M: Perspective: fundamental and clinical concepts on stem cell homing and engraftment: a journey to niches and beyond. Exp Hematol 2005;33:9-19.

80 Cilloni D, Carlo-Stella C, Falzetti F, Sammarelli G, Regazzi E, Colla S, Rizzoli V, Aversa F, Martelli MF, Tabilio A: Limited engraftment capacity of bone marrow-derived mesenchymal cells following T-cell-depleted hematopoietic stem cell transplantation. Blood 2000:96:3637-43. 